\title{
Did Catherine the Great of Russia have syphilis?
}

\author{
R S Morton
}

\begin{abstract}
Catherine the Great (1729-96) ruled Russia for the last 34 years of her life. She pursued many reforms with energy, intelligence and political shrewdness. Not least amongst her activities was a serious interest in matters of public health which extended to personal involvement in the care of the venereally infected. This paper suggests that perhaps her zeal in this last was based on more than social awareness.
\end{abstract}

\section{Introduction}

Catherine II came to power after a coup d'état in 1762 when she was 33 years old. She was born, in 1729, Princess Sophie of Anhalt-Zerbst in the Baltic borderland between Poland and Russia. She grew into an athletic, spirited girl of high intelligence. She was well educated in an orthodox Lutheran family with apparently a greater fondness for her orderlyminded, military father than for her rather quixotic mother. She was thus admirably fitted to fulfil her mother's ambitious plans; plans which in time became her own hopes. At the invitation of Empress Elizabeth of Russia she and her mother travelled to Moscow to meet the Empress's heir apparent. In spite of a severe attack of pneumonia or pleurisy on arrival she went ahead with a crash course in Russian. At the instigation of the domineering Empress she became engaged to her son the Grand Duke Peter, some 15 months her senior. She was 15 years old. ${ }^{1}$

Peter was not very bright. He was also lamentably immature with a lack of grace and manners. His behaviour, often childish, was described as appalling. Throughout his life he displayed a passion for playing at soldiers with both toys and men. In addition to his lack of good looks, a severe attack of smallpox resulted in marked facial disfigurement. Catherine became saddened and clinically depressed at the prospect of marrying an ugly oaf. Later she described him as "subtle, like a cannon shot."2

University of Sheffield

Home address: 9 Cortworth Road, Sheffield S11 9LN, UK

R S Morton
The Marriage (1745-62)

The marriage was organised by the Empress Elizabeth. It remained unconsummated for nearly nine years. The Grand Duke's "military mania" prompted Catherine to write in her memoirs "Nothing is so bad as to have a child for a husband." 3 In correspondence with the British Ambassador, (from 1756) Sir Charles Hanbury-Williams, ${ }^{45}$ Catherine gave some idea of the mental misery she endured at the hands of the tyrannical Empress. Any friends she made at court were removed. At times she was deprived of all society, forbidden to write to her mother, chided about her lack of children and mocked about her virginity. ${ }^{6}$ Little wonder that alone, friendless and oppressed she contemplated suicide. ${ }^{4}$

On the organic side her medical history in the earlier years of marriage included severe measles (thought at first to be smallpox), toothache (on one occasion with dental abscess), a five day rash on her face, bouts of diarrhoea and occasional fevers, one prolonged with delirium and a spell of unconsciousness. ${ }^{4}$

Public and regal concern prompted the Empress to appoint an "adviser" to encourage Catherine to make her own arrangements about pregnancy. ${ }^{2}$ Thus she lost her virginity to Serge Saltikov, a Guards officer, in the summer of 1752. Saltikov was then two years married and described as a boastful and practised seducer. $^{2}$ There were early disappointments. Catherine had two miscarriages, one on 20 December 1752 when at least two months pregnant and the other on 30 June $1753 .^{7}$ Thereafter she was very ill for 13 days. According to her memoirs "... They suspect that part of the afterbirth has not come away ... on the 13th day it came out by itself." 8 Both these pregnancies were attributed to Saltikov. ${ }^{9}$

Meanwhile arrangements were made for husband Peter to be instructed-both theoretically and practically-in his marital duties. All was made clear to him by a hired widow. He appears to have been circumcised at this time. ${ }^{2}$ The married couple probably experienced their first coitus late in 1753 or early the following year, that is some months after the loss of the second pregnancy.

On 20 September 1754 Catherine delivered herself of a son, destined to become Czar Paul I. Saltikov, his duties apparently completed, was given a post in France. 
The babe was immediately removed to the Empress Elizabeth's quarters where he remained for his early years. He proved to be delicate and frail and was often ill. Temperamentally and intellectually the child grew to resemble his dull and defective royal father. ${ }^{2}$ Many, however, believed his blonde hair and big, limpid, brown eyes indicated that he was the son of Serge Saltikov. ${ }^{10}$ At nine years of age he had a severe fever which it was said left him subject to nervous fits. He grew into a very introverted adult.

Catherine's second lover was Count Stanislas Poniatowski, later to become Stanislas Augustus, King of Poland. The affair lasted from 1755 to 58. Their child Anne, born 9 December 1757, survived for little more than one year. The cause of her death has not been determined. Again Catherine was denied the pleasures of mothering her child.

When the Empress Elizabeth died on Christmas day 1761, Catherine was five months pregnant to her third lover, war hero Gregory Orlov. The affair had been running for over a year. The boy child was born on 11 April 1762 and promptly placed for adoption. The pregnancy had led to strained relations and subsequent estrangement between Catherine and her husband, now Czar Peter.

As a ruler Peter was a hopeless failure and it soon became clear throughout the land that his bizarre behaviour rendered him quite unfit to rule. A simple and efficient bloodless coup d'état was arranged and carried through in June 1762 by Gregory Orlov with the help of his four brothers, all of them Guards Officers. The army and the people gave a great welcome to their new Empress Catherine. Neither was to regret it. A week later the Czar met his death, alleged accidentally, during a drunken brawl. He was then under the care of one of the Orlov brothers who begged for and was granted Catherine's forgiveness.

Thus ended Catherine's virtual imprisonment in a miserable marriage in which the Empress Elizabeth had been her jailer in chief. This period of Catherine's life is enshrined in her epitaph written by her own hand "Eighteen years of tediousness and solitude caused her to read many books ...."." This practice was to prove a fine and fulsome preparation. It matched her patient and singleminded dedication to duty and ambition. If character means drilling oneself in hazard avoidance, few monarchs have been better equipped (fig 1).

\section{Catherine as Empress}

Catherine proved herself to be a consistently hardworking, thoughtful, audacious and brilliant political strategist. She aimed to Europeanise and secularise Russian society. This applied in both home and foreign affairs. Her great energy and powerful concentration she deployed through effective and efficient working routines. Her decision-making was based on data collecting, common sense, sound self-control and, when indicated, an iron will. Her catholic interests reflected her wide reading concerning the arts, architecture, philosophy, international relations, the conduct of wars and not least the law. No biographer takes a contrary view. Some idea of her sense of application to the needs of her people for reforms can be appreciated from a review of her first 18 months as Empress. Some three hours of her 15 hour working day were spent writing her "Instructions". Some 600 of the 1200 pages are in her own hand. These guidelines-the distillation of many surveys, discussions, conversations with advisers and much international correspondence-are remarkable. The first version was published in December 1766. One of her ministers, Count Nikiti Panin, said of them "These are principles to throw down walls". ${ }^{12}$ One might be forgiven for seeing this as a shadow cast by coming events of our own time.

\section{Catherine and the Public Health}

Following the line of her "Instructions" Catherine set up a Medical Commission to report on the state of the public health. High on her list of priorities was the infant mortality rate. Lying-in hospitals and Foundlings' homes were among the more specific responses that featured on the list of expansions of services. ${ }^{13}$

From her multiple sources of data she had learned that men such as John Haygarth in England were recognising that "nearness" was a vital factor in the spread of disease and indicated a need for isolation in special fever hospitals. She instructed her Ambassador in London to provide her with up-to-date information. In the event it was John Fothergill who recommended Thomas Dimsdale as the doctor best suited to vaccinate Catherine and her son Paul against smallpox in October 1768. ${ }^{14}$ Following her example several million Russians were vaccinated within a few years. ${ }^{15}$ Such personally led endeavours challenged obscurantism and defied the quasiChristian fatalism then current in Russia. ${ }^{16}$

In 1771, with bubonic plague set to kill 60,000 , some $300-400$ per day in Moscow alone, the Empress stayed in the capital and deployed the remarkable organisational abilities of Gregory Orlov in an effective containment of the epidemic. ${ }^{17}$

Catherine's first publically declared interest in veneral disease appears in her "Instructions" where we find: ". . . two hundred years are now elapsed since a disease unknown to our ancestors was imported from America and hurried on to the destruction of the human race. This disease spreads wide its mournful and destructive effects in many of our Provinces. The utmost care ought to be taken of the health of our citizens. It would be highly prudent 


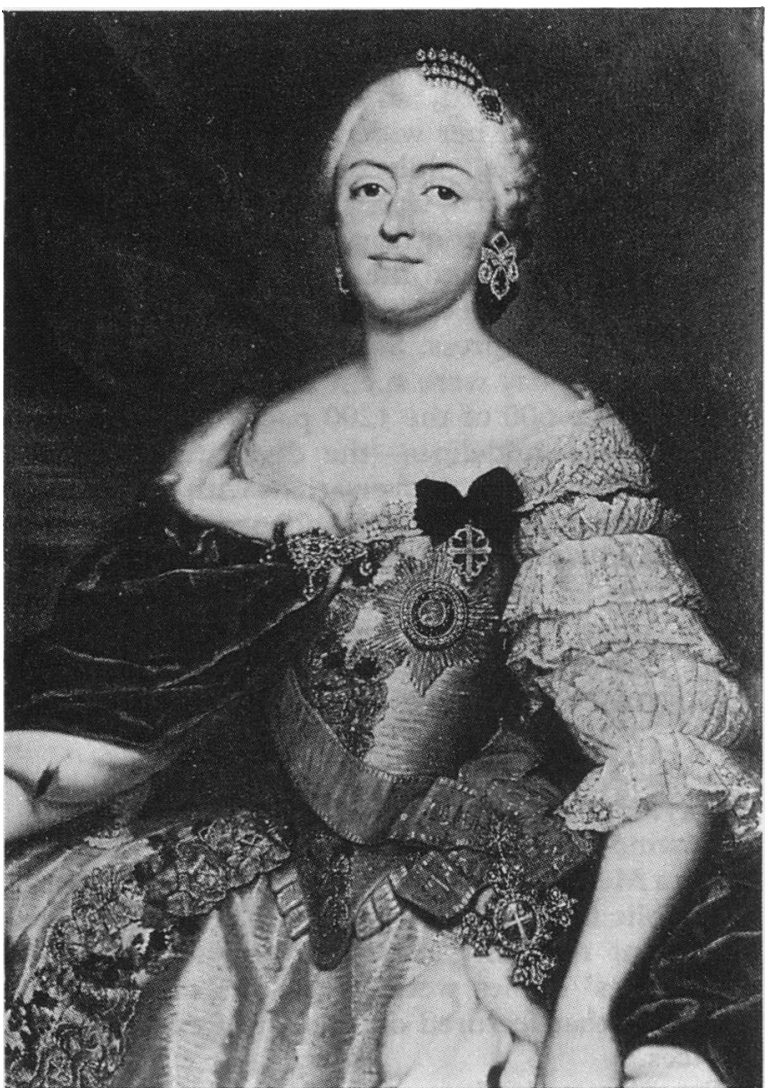

Fig 1 Catherine the Great as Empress Catherine II. Probably at age of 37 in 1766 when she completed her first issue of the "Instructions". The artist is unknown as is the painting's present whereabouts. It was known to be in the possession of a Viscount Powerscourt in 1928.

therefore to stop the progress of this disease by the laws." 16

As elsewhere in the world at the time, syphilis and gonorrhoea were regarded in Russia as one and the same condition and a major public health concern. The numbers infected tended to overburden hospital facilities. Catherine's survey data showed that $20 \%$ of 671 hospital patients in St. Petersburg had syphilis. Infection rates in the armed services were alarmingly high. Forty-five infections were found in 417 Moscow infantrymen and 49 of 1070 naval personnel were similarly affected in Kronstadt, the Baltic naval station. Catherine recognised the spread of veneral infection within families and was horrified by this and its association with shortened lives. ${ }^{13}$

In 1770 in St. Petersburg (presently called Lenningrad) Catherine established and maintained at her own expense the world's first hospital devoted exclusively to the care of patients with venereal disease. It had 60 beds, 30 for each sex. Her personal instructions were that patients' names were to be used only for registering applications for admission.
Confidentiality and secrecy were to be emphasised and respected at all times. ${ }^{13}$

Even allowing for Catherine's distinguished personal involvement in furthering her people's health and welfare, this insistence on respectful, liberal and compassionate care of the venereally infected exhibits a degree of meritorious service far beyond the call of duty. Only one other monarch is known to have shown direct and active interest in such patients. This was the equally intelligent, energetic and socially aware James IV (1473-1513) of Scotland who in travels round his Kingdom dispensed money to patients with the new epidemic disease. ${ }^{18}$

Above the entrance to the third Dumfries Infirmary, built 1975, one finds its old motto "Miseris Obitulando Augear"-(By giving help to the sick, the giver himself becomes enriched). Does this explain the actions of Catherine and James? Or is generosity of spirit based on some devastating personal experience? James IV wore a skin-tight chain mail belt as a penance for his part, when aged 15 years, in his father's death. ${ }^{18}$ Does it perhaps need some secret

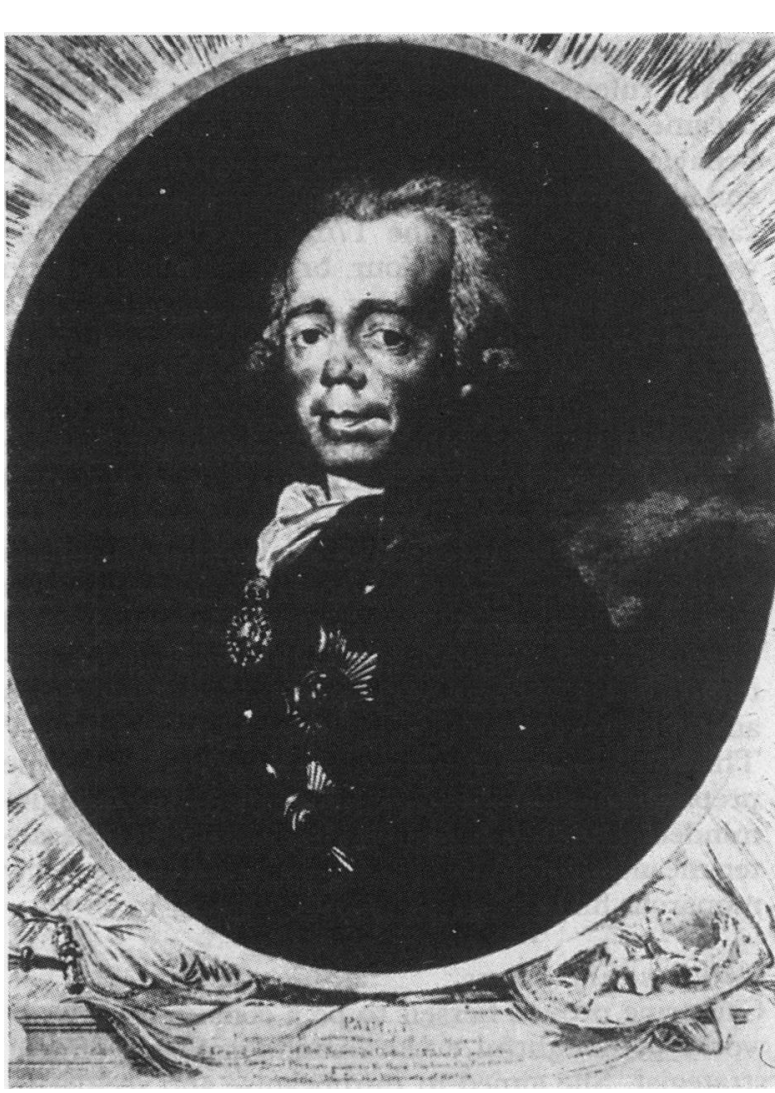

Fig 2 Paul I, son of Catherine the Great. An engraving from a painting by $V L$ Borovikowsky (1759-1825). The whereabouts of both is unknown. 
sorrow to engender public regal compassion? Is there anything of this nature in Catherine's life history?

\section{Catherine's "private" life}

By all accounts, Catherine was 23 years old when she first took a lover. Like many socially outgoing, intelligent and boldly successful women she was to show a strong sexual appetite. She had, in all, 12 lovers over some 43 years. Her love life might well be described as based on serial monogamy. Her most long-lasting affair, some 12 years (1759-72), was with Gregory Orlov. Not more than two of the men in her life-most of them fine physical specimens from Guards regiments-came near to matching her intellectually or even socially. One of them, Potemkin, she may have married secretly. At least two of her lovers were recognised debauchees. Another, her 7th, with a fine war record, was described as an unkempt illiterate Serbian hussar. Two in her later years could be described as "toyboys". Clearly she enjoyed a wide variety of physical and intellectual satisfactions.

Of her relationships with men she wrote "One cannot stop half way in the tempting/tempted process. When emotion intervenes one is already much further involved than one realises." 19 In a wonderful love letter declaring her passion for her absent "Sir hero", Potemkin, with whom she shared many and varied triumphs, she writes ". . my heart would not willingly remain one hour without love." 20

Catherine appears to have been well aware that association with armed services personnel put her "at risk". She ordered her personal physician (from 1769), John Rogerson of Edinburgh, to examine her intended lovers and certify them free from infection. ${ }^{21}$ In addition she employed her lady-in-waiting, Baroness Bruce, as éprouveuse. This lady who clearly grew tired of waiting, was dismissed when Catherine found her in flagrante delicto with one of her younger lovers, Ivan Rimsky-Korsakov of that ilk. ${ }^{22}$

There is nothing in Catherine's medical history to suggest that she ever had primary or secondary syphilis. The primary sore appears on the cervix of 25 per cent of infected women and the secondary stage in them is more often mild and undiagnosed than in men. However, Catherine's early obstetric history is suggestive. Her first pregnancy is said to have ended after more than two months of pregnancy. From what we know it could have been a month or more longer. The second miscarriage with an observed placenta, generally regarded as essential to foetal infection, certainly raises one's index suspicion. Both of these pregnancies, (and some thought the third also), were attributed to Serge Saltikov, a known libertine, a member of the armed forces and readily recognisable as a risky sex partner. The first live child, Paul, was a sickly infant and the product of the fourth

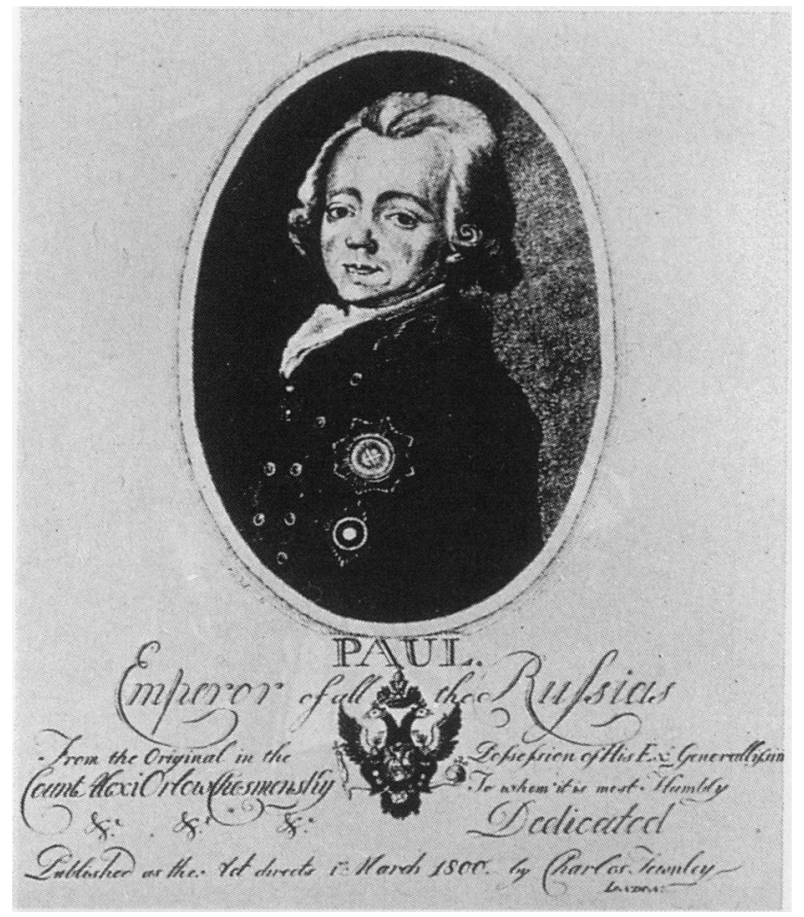

Fig 3 Paul I, son of Catherine the Great. Painter unknown. Housed in Stat Museum, Leningrad. ( $A$ variant of this painting is said to be in the possession of a Count Bobrinsky. The original is said to have been possessed by one of the Orlov brothers.)

pregnancy, Anne, died at about one year of age. There is nothing in the early history of either infant to warrant a diagnosis of neo-natal infectious congenital syphilis or treatment relative to such a diagnosis. There is no record of any further miscarriages in Catherine's obstetric history. Nor is there anything suggestive of interstitial keratitis or eighth nerve deafness in any of her children. She had at least two more successful pregnancies. Catherine's early obstetric history hints at, and some would think is compatible with Diddy's Law of Decrease; sometimes called Kassowitz's law. This lays down that syphilitic women carry a series of foetuses, each successive one tending to show less evidence of congenital infection than its predecessor.

But more is needed to establish a diagnosis of syphilis in Catherine. There is nothing significant in her subsequent medical history. She died of a stroke after being unconscious for 48 hours. What about her sexual partners? If she did have syphilis resulting in a demonstration of Diddy's Law of Decrease, then clearly Saltikov would be her primary or source contact. Alas, no record has been found of his medical history or that of his wife and her pregnancies. Catherine's second lover (from 1755-58), Stanislas Augustus Poniatowski (1732-98) apparently died of 


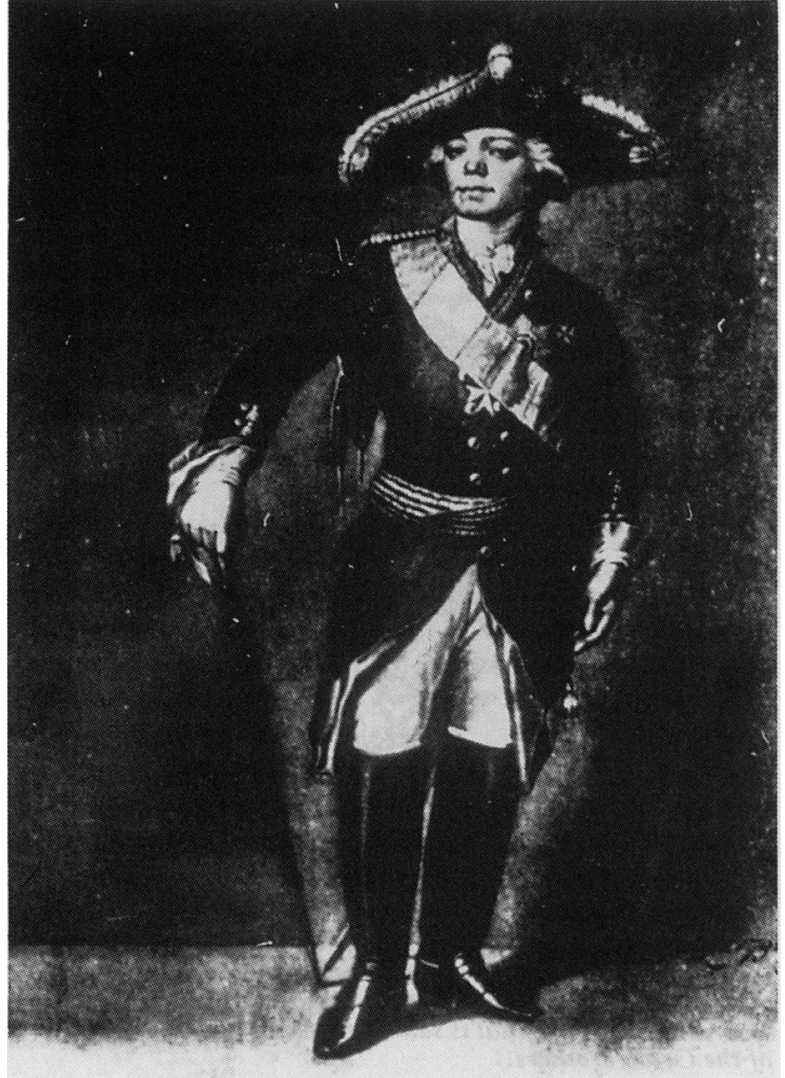

Fig 4 Paul I, son of Catherine the Great. Copy of a painting by $E$ Schulkin, 1791 (said to be by one called Gardiner), which is housed in an unknown museum, allegedly in Leningrad.

natural causes in St. Petersburg. Nothing has been found to suggest that he may have acquired syphilis from Catherine. The same applies to Catherine's husband. Gregory Orlov, although he died insane "with fits of the palsy" 23 in 1773, did not enter Catherine's life until 1758, too late to be infected by any syphilis Catherine may have acquired in $\mathbf{1 7 5 2}$. The infection is rarely, if ever, contagious for more than four years.

Our only hope of confirmation of a diagnosis of syphilis in Catherine lies therefore with her son Paul. The boy's mentally defective state closely resembled that of his legal father. In both cases the condition dated from infancy and was non-progressive. The boy had no problem with his sight or hearing. People did comment, however, on his facial appearance. One description says he looked like a bulldog ${ }^{24}$ and another says he resembled a pekinese..$^{25}$ Of several portrait paintings, two in particular confirm this. They show Paul's receding forehead and chin. The bridge of his nose is broadened and flattened. Most striking of all, however, is the impression that his whole face has been pushed in. He has the "dish face" typical of congenital syphilis (figs $2 \& 3$ ). The full length painting (fig 4) hints at confirmatory bowing of the tibiae.

\section{Conclusions}

Do Catherine's endeavours on behalf of the venereally infected and her personalised safer sex precautions signify that she knew more of self involvement with syphilis than she ever openly revealed? Do her actions speak louder than words?

Did she perhaps share her secret doubts and sorrow with Dr Rogerson? They were quick to establish a close relationship. Was it his counsel and confidential care that led her to insist that all in such need should be no less privileged?

From all we know of Catherine, affirmative answers to these questions seem eminently rational. At all levels of her life she gave herself thoughtfully and unstintingly. In her political, social and sexual life her successes owe much to her capacity to surrender herself totally - a rare and occasionally hazardous gift.

Together, the social, epidemiological, clinical, iconographic and personal factors make a diagnosis of syphilis in Catherine the Great much more likely than not.

1 Haslip J. Catherine the Great. London, Weidenfeld \& Nicolson, 1977, pp 1-30.

2 Ibid pp 42-57.

3 Catherine the Great, Memoirs of, Translated by Katherine Anthony (from the German edition edited by Erich Boehme and published by Insel-Verlag, Leipzig, 1879). New York and London, AA Knopf, 1927, pp 258-61.

4 Ibid pp 231-244.

5 Catherine the Great. Correspondence with Sir Charles HanburyWilliams, ed. London, Ilchester and Longford-Brooke, 1928.

6 Op. cit. See 3 above, pp 199, 244.

7 The Memoirs of Catherine the Great. Edited by M Morager, London, Hamish-Hamilton, 1955, pp 205-218.

8 Troyat $\mathrm{H}$. Catherine the Great. English translation by Aidan Ellis. Oxford, Aidan Ellis, 1978, pp 66-72.

9 Op. cit. See 1 above, p 58.

10 Coughlan R. Elizabeth and Catherine, Empresses of All the Russias. London, MacDonald and James, 1975.

11 Op. cit. See 3 above, p 326.

12 Ibid $\mathrm{p} 306$.

13 Alexander JT. Catherine the Great and Public Health. $J$ Hist Med 1981;36:185-204.

14 Fox RH. Dr Fothergill and his Friends. London, Longman Green, 1919, pp 167-170.

15 Cronin V. Catherine, Empress of All the Russias. London, Collins Havril, 1989, pp 167-170.

16 Documents of Catherine the Great. Correspondence (in French) with Voltaire (1763-77) and the "Instructions" of 1767 in English text of 1768 . Ed by WF Reddaway, Cambridge, Cambridge University Press, 1931, p 314.

17 Op. cit. See 1 above, p 194-206.

18 Morton RS. Some aspects of the early history of syphilis in Scotland. Br J Venereal Dis 1962;38:175-9.

19 Op. cit. See note 7, p 301.

20 Op. cit. See note 3, p 326.

21 Op. cit. See note 1, p 259.

22 Op. cit. See note 1, p 275.

23 Op. cit. See note 1, p 298.

24 Op. cit. See note 8, p 76.

25 Op. cit. See note 14, p 202.

Accepted for publication 2 September 1991 